\title{
O papel das cidades-gêmeas da região norte brasileira na articulação do comércio exterior
}

The role of the twin cities of the Brazilian North region in the articulation of foreign trade

\author{
Leonardo Luiz Silveira da Silva \\ Geógrafo, mestre em Relações Internacionais e doutor em Geografia - Tratamento da Informação \\ Espacial PUC-Minas, Brasil \\ leonardo.silveira@ifnmg.edu.br \\ Renato de Oliveira Marques \\ Geógrafo, mestre em Geografia - Tratamento da Informação Espacial PUC-Minas, Brasil \\ bhgeotecnologia@gmail.com
}

\begin{abstract}
Resumo
Este artigo propõe dimensionar a força comercial dos oito municípios da região norte brasileira que abrigam cidades-gêmeas. Utilizando-se dos ricos dados disponíveis pelo ministério da economia brasileiro sobre exportação e importação em nível municipal, serão analisadas detidamente as cidades-gêmeas por meio de sua posição urbana, parceiros comerciais e participação ou não dos benefícios advindos dos termos do regime das Áreas de Livre Comércio (ALCs). Verifica-se que a posição lindeira é ao mesmo tempo um benefício e um desafio ao comércio, à medida que, se por um lado, o contato direto com os territórios estrangeiros facilita o intercâmbio, por outro, as fragilidades notórias quanto à integração às redes de transporte encarecem os fretes de mercadorias. Conclui-se também que o regime das ALCs favorece o desenvolvimento econômico das cidadesgêmeas que dele desfrutam, mas pouco colabora para o fomento do comércio exterior. $\mathrm{O}$ artigo atenta-se ainda para algumas particularidades regionais subjacentes, como o comércio informal praticado pelas migrações pendulares, que não entra nas estatísticas oficiais do comércio exterior. Aponta, outrossim, a oscilação cambial como um importante fator da orientação das relações econômicas internacionais protagonizadas pelas cidades-gêmeas.
\end{abstract}

Palavras-chave: Cidades-gêmeas; Comércio Exterior; Região norte; Áreas de Livre Comércio.

\begin{abstract}
This article proposes to measure the commercial strength of the eight municipalities of the northern Brazilian region that contemplates twin cities. Using the data available from the Ministry of the Brazilian economy on export and important $t$ the municipal level, the twin cities will be analysed in detail through their urban position, commercial partners and participation or not the benefits derived from the terms of the ALC's regime - Free Trade Areas. At the same time, the urban position is a benefit and a challenge to trade, as long as, on the one hand, direct contact with foreign territories facilitates Exchange, on the other hand, the perceived weaknesses in the integration of transport networks make freight expensive. It is also concluded that the ALC regime favours the economic development of the twin cities, but does little to foster foreign trade. The article also looks at some regional particularities, such as the informal trade practised by pendular migrations, which does not register into official foreign trade statistics. It also points to the exchange rate oscillation as an essential factor in the orientation of the international economic relations carried out by the twin cities.
\end{abstract}

Keywords: Twin Cities; Foreign trade; North region; Free Trade Areas. 


\section{INTRODUÇÃO}

A grande extensão da faixa de fronteira brasileira motivou, ao longo da história de formação territorial do Brasil, a incidência de tratativas diplomáticas e políticas governamentais sobre estes espaços estratégicos. Balanceando as prioridades da fronteira entre as preocupações de cooperação e de segurança, o Estado brasileiro vem estabelecendo políticas que visam a territorialização destes espaços. A fronteira brasileira tem sido alvo de preocupação da gestão do espaço nacional. Por meio de suas políticas espaciais, o Brasil reconhece os desequilíbrios no desenvolvimento econômico, estrutural e populacional do conjunto territorial nacional, causados, dentre outros, pela sua histórica vocação atlântica.

Para além do Brasil, apresenta-se como ameaça contemporânea à soberania nacional uma tendência para a proliferação de leis, normas e regras no interior dos territórios que são válidos para certos setores e lugares, mas não para outros (MACHADO, 2000), fenômeno chamado por Betrand Badie (1999) de "aluguel de soberania". Nesse sentido, a fronteira acaba se constituindo palco de políticas territoriais agressivas que podem ser entendidas como tentativas de territorializar espaços periféricos outrora mal assistidos pelos governos. Além disso, tais políticas apresentam-se como formas de competir economicamente com espaços adjacentes que estão além das fronteiras nacionais.

$\mathrm{Na}$ discussão sobre as fronteiras, destacam-se os estudos sobre as cidades-gêmeas. Como se tratam de cidades inseridas nas faixas de fronteira, esta tipologia urbana se caracteriza pela concentração econômica e demográfica, fazendo com que neles sejam mais visíveis as grandes questões que permeiam a vida fronteiriça. Focando nas oito cidades-gêmeas da região norte brasileira, este artigo traça o atual cenário das cidades no que tange à articulação dos fluxos comerciais internacionais por meio de dados de importação e exportação de mercadorias que nelas são registradas. Sabe-se que cinco dos oito municípios que abrigam as cidades-gêmeas aqui avaliadas desfrutam da política territorial das Áreas de Livre Comércio (ALC), que contempla a possibilidade da realização de importações sem tarifas, dentre outras vantagens. Como veremos, mesmo com esta política, a maior parte das cidades-gêmeas da região norte brasileira participam de forma irrisória do comércio internacional. O artigo propõe uma reflexão sobre o papel da posição geográfica destas cidades, dentre outras características, como meio para a explicação dos fluxos comerciais incipientes, lançando uma crítica aos resultados comerciais que vem sendo obtidos por meio da vigência dos termos das ALCs. 


\section{REFLEXÃO SOBRE OS LIMITES E AS FRONTEIRAS}

Os estudos de limites e fronteiras possuem uma história longa, descritiva e, pelo menos em boa parte do seu percurso, pobre no que se refere ao debate epistemológico. Em parte, isto é explicado pelo fato destas categorias serem materializadas como uma questão das relações internacionais baseadas em princípios práticos e, em alguns casos, técnicos (NEWMAN; PAASI, 1998). Por outro lado, sabemos que no senso comum, limites e fronteiras são palavras utilizadas em sentidos que não condizem com o seu significado geográfico. Isto se deve, também, pelo fato do estudo destas duas categorias não ser exclusividade da Geografia, sendo objeto de estudo de antropólogos, cientistas políticos, sociólogos, planejadores urbanos, estudiosos ambientais, dentre outros (TAGLIACOZZO, 2015). Cada uma destas disciplinas conceitua os limites e as fronteiras com ênfases variadas. Entretanto, o consenso é de que estas duas categorias são construções humanas, criadas para controlar o comportamento humano em um contexto espacial (HATALEY; LEUPRECHT, 2018).

A partir de uma abordagem centrada na multidisciplinaridade, consideramos que o limite é uma linha natural ${ }^{1}$ ou artificial que contorna o extremo do território físico do Estado. O limite jurídico do território é uma abstração que, por ser reconhecida como definidora do espaço territorial, acaba se constituindo como um instrumento de separação entre unidades políticas e soberanas (MACHADO, 2000).

A fronteira, por sua vez, é a faixa contígua à linha do limite. Temos, a partir destas definições, clareza quanto às distintas geometrias entre os limites e as fronteiras. Estas últimas possuem usualmente sua extensão artificial, definida a partir dos interesses do Estado que as abriga. Como normalmente os Estados estabelecem a extensão da faixa de fronteira, são diminutas as brechas para as interpretações subjetivas deste valoroso conceito geográfico. Em grande medida, esta é a explicação para que os estudos de fronteira gradativamente tenham passado a entender as fronteiras como instituições que resultam das políticas de fronteira (Brunet-Jailly, 2012a), em contraste com a ideia simples de linhas desenhadas na areia ou em um mapa. Como toda instituição, as fronteiras possuem um rol de regras internas que dirigem o seu comportamento, alguns dos quais se transformam resistentes às mudanças (NEWMAN, 2003). Contudo, as regulamentações da fronteira são passíveis de experimentar mudanças.

Há duas interpretações para a origem etimológica da palavra fronteira. A primeira remete à palavra "fronteria" ou "frontaria", indicando a porção do território situado "in fronte", ou seja, nas margens. A segunda estaria ligada a palavra "front" ou "la ligne de front", dando um sentido

\footnotetext{
${ }^{1}$ De Acordo com Antônio Carlos Robert de Moraes, a maior fetichização demarcatória dos limites e das fronteiras do território está “em toma-las como naturais. Isto é, ver aquelas linhas demarcatórias dos domínios espaciais dos Estados como acidentes geográficos da superfície terrestre (MORAES, 2005, p.77)
} 
militar-estratégico à região da fronteira e sugerindo ser esta uma área marcada por tensões, onde as soberanias territoriais se encontram (NOGUEIRA, 2007). A distinção entre regiões de fronteira e linhas fronteiriças (limites) é significativa para se estabelecer os diferentes sentidos da fronteira para os Estados modernos e os tradicionais (estes, pré-vestfalianos, como os impérios romanos e chineses). Nos Estados modernos, a fronteira é melhor delimitada, possuindo limites que definem a espessura de sua faixa. Nos Estados tradicionais, a ideia de fronteira era expressa como uma zona, sem delimitação muito precisa (CAIRO CAROU, 2001).

A despeito do uso do senso comum, que aplica o conceito de fronteira às mais diversas realidades, confundindo-o, inclusive, com o conceito de limite (MATTOS, 1990), temos nos estudos geopolíticos e da Geografia Política definições muito claras e desprovidas de ambiguidades. A fronteira constitui-se no campo dos estudos políticos aplicados ao espaço como uma área convencionada que segue as normas do direito internacional como, também, as leis e constituições dos interessados em delimitá-la (ABINZANO, 2015). Por esta razão, a extensão da Faixa de Fronteira varia de acordo com as resoluções de cada país. Geralmente sua extensão integra o texto da carta magna, como ocorre no Brasil.

Se as fronteiras e os limites existem, sempre haverá alguém disposto a atravessá-los para acessar o outro lado. O gerenciamento de fronteiras possui como escopo os procedimentos necessários para facilitar ou restringir a sua travessia (NEWMAN, 2006). No caso brasileiro, assim diz o trecho da constituição que aborda a extensão da faixa de fronteira: "A faixa de até $150 \mathrm{~km}$ de largura, ao longo das fronteiras terrestres, designada como faixa de fronteira, é considerada fundamental para a defesa do território nacional e sua ocupação e utilização serão regulamentadas por lei” (BRASIL, Cap.II, Art.20, alínea XI, parágrafo II, 1988).

Poucos países podem ter faixa de fronteira com a extensão de $150 \mathrm{~km}$, sob o risco de muitos deles possuírem a totalidade ou mesmo a maior parte dos seus territórios inseridos no interior desta faixa. Com dimensões territoriais colossais e com uma das mais extensas faixas de fronteira do mundo, sendo parte importante delas em zonas despovoadas que geram apreensão quanto à segurança e integridade territorial, o Brasil tem motivos para se tornar um expoente nos estudos fronteiriços.

Os limites e as fronteiras são produzidos a partir das dinâmicas de territorialização e territorialidade. Estudos sobre a formação territorial dos países costumam ser riquíssimos e permeados de tratativas diplomáticas e eventos beligerantes. Arranjos e rearranjos das redes são instrumentos eficazes e indispensáveis para a compreensão de processos de ampliação e fragmentação territorial.

As fronteiras terrestres são as de questionamento mais antigo. Em função disto encontra-se bastante consolidado no direito internacional a regulação do seu traçado e de sua funcionalidade. Há 
de se destacar que a aceitação de uma linha de limites pelos países confinantes, seja ela natural ou artificial, não deve dispensar a necessidade de sua demarcação física. As mais diversas fronteiras naturais possuem regras de demarcação bem claras (MATTOS, 1990).

As relações de um poder territorial com a sua faixa de fronteira não pode ser entendida como algo permanente que perpassa pelo tempo e pelos governos e regimes políticos. As faixas de fronteiras experimentam mudanças que estão diretamente associadas a fatores como:

- novo dinamismo nos territórios fronteiriços adjacentes. Mudanças rápidas na faixa de fronteira do vizinho muitas vezes sugerem uma reação no que tange ao ordenamento da gestão territorial desta região estratégica do Estado;

- mudanças governamentais que implicam em modos diferentes de se ver a fronteira. Geralmente estas mudanças implicam em um rearranjo do equilíbrio entre as funções de segurança e de plataforma de cooperação, não sendo este equilíbrio, necessariamente, um jogo de soma zero;

- mudanças internacionais que passaram a exigir mais fluidez e porosidade nos fluxos internacionais, com o barateamento dos custos de transporte em escala global;

- o enfraquecimento institucional do Estado, que pode ser menos capaz de fazer valer sua presença nas áreas periféricas, permitindo o surgimento de múltiplas territorialidades e o aumento das relações informais transfronteiriças;

- o status quo diplomático que envolvem os países que compartilham a zona de fronteira. Por exemplo, as diferenças observadas entre a zona de fronteira alemã e francesa é bem distinta daquelas observadas entre a Coreia do Sul e do norte. O status diplomático é um dos principais vetores da diferença em questão.

A fronteira brasileira conta com um expressivo número de cidades-vigilantes, criadas junto ou próximas ao limite internacional do Brasil consolidado após o Tratado de Madri (1750). As cidades-gêmeas têm na função de cidades-vigilantes um dos seus importantes pilares fundadores. Mais densas na porção meridional no Brasil, as cidades-vigilantes também marcam presença nas regiões centro-oeste e norte. Fundadas em outro contexto territorial, estas cidades desempenham um importante papel de territorialização do espaço nacional ao se constituírem como importantes nós das redes nacionais e transnacionais. Contudo, a sua posição periférica se traduz em sacrifícios práticos: a dificuldade de integração com a malha de transportes nacionais, pouca diversidade e/ou qualidade de equipamentos urbanos, inserção em áreas de redes urbanas regionais pouco 
desenvolvidas $^{2}$ (SANTOS, 2008) e fraca atuação dos aparatos de fiscalização do Estado (que acabam conduzindo a prejuízos na arrecadação fiscal e evasão de divisas).

Centros urbanos muito espaçados entre si são o sinal e a causa da fraqueza dos fluxos para eles direcionados. A periferia amazônica destaca-se por ser uma zona de subpovoamento, dotada de redes com baixa densidade de fluxos. No conjunto das redes brasileiras, enquadra-se na periferia da periferia. As redes, que são a alma do território e seu constituinte (RAFFESTIN, 1993), apresentamse na região norte brasileira incipientes e rarefeitas, estabelecendo precária territorialização.

\section{AS CIDADES-GÊMEAS}

As cidades-gêmeas constituem-se como pontos nevrálgicos das mais diversas redes sobrepostas, sendo a sua posição geográfica um dos seus maiores trunfos. Por isso, não raramente são referidas com nós de alta hierarquia das redes que integram (CAMPOS, 2017). Inseridas nas faixas de fronteiras dos seus países, estão sitiadas em regiões que inspiram preocupação quanto à segurança, proteção e soberania nacional. Além disto, apresentam intensa diversidade econômica, social e cultural (MACEDO, 2017). Localizadas na periferia territorial do Brasil e da Bolívia, as cidades-gêmeas do norte do Brasil estão posicionadas em áreas portadoras de um ecossistema frágil, relativamente pouco alterado pelo homem. Contudo, as dificuldades de fiscalização das autoridades interferem negativamente na busca do equilíbrio entre as ações desenvolvimentistas e a preservação ambiental. É importante ressaltar que nem sempre encontramos, nos estudos das cidades-gêmeas, centros urbanos inseridos em vazios demográficos, dotados de população pouco expressiva. Apesar de ser esta a condição dominante de boa parte da fronteira brasileira, temos no continente africano, por exemplo, uma conurbação de 13 milhões de habitantes formada pelas cidades de Kinshasa (República Democrática do Congo) e Brazaville (República do Congo) (SOI; NUGENT, 2017).

$\mathrm{Na}$ literatura, as cidades-gêmeas são definidas como espaços híbridos compostos por elementos nacionais e internacionais (COELHO, 2013; TERENCIANI, 2012). Muitas vezes submetidos ao convívio diário com cidadãos de distintas nacionalidades, o habitante das cidadesgêmeas constrói e reconstrói permanentemente noções sobre a identidade e a nacionalidade (VIRGA, 2017). Os conceitos formados, mesmo considerando a possibilidade de sua ressignificação e dinamismo, podem se constituir como barreiras ou mesmo incentivos para as relações transfronteiriças.

\footnotetext{
${ }^{2}$ Milton Santos caracteriza as redes urbanas pouco desenvolvidas desta forma: “(...) observa-se que as redes lineares ou em espinha de peixe ocorrem com frequência, enquanto que as transversais são bastante raras, como é o caso, por exemplo, da África tropical. A essa simplicidade de traçado responde uma fraca densidade da "rede" de cidades, relacionada seja com o "subpovoamento" do país, seja com sua "suburbanização"; a distância entre os centros urbanos é, ao mesmo tempo, sinal e causa da fraqueza das trocas (SANTOS, 2008, p.158).
} 
Há algum espaço para desacordos conceituais sobre o que sejam cidades-gêmeas. Para o olhar brasileiro, definido pelo Ministério da Integração, as cidades podem ser consideradas gêmeas se possuírem:

- a população mínima de 2.000 habitantes (definição objetiva);

- município que abriga o seu sítio urbano ser cortado pelo limite internacional (definição objetiva);

- grau elevado de integração econômica e cultural (definição subjetiva) (BRASIL, 2005).

Vê-se que, mediante estas variáveis delimitadoras, uma grande pluralidade de núcleos urbanos bem distintos entre si incorporam a classe de cidades-gêmeas. Como exemplo, CorumbáMS, que possui pouco mais de 90.000 habitantes, trata-se de uma cidade-gêmea tanto quanto Assis Brasil-AC, que possui cerca de 7.000. Acrescenta-se às assimetrias demográficas diferenças de outros tipos tais como a existência de cidades-gêmeas conurbadas ou não, inseridas em redes urbanas densas (principalmente no sul do Brasil) ou em desertos urbanos (principalmente no arco norte da fronteira brasileira), bem ou mal acessada por transportes e, ainda, inseridas em diferentes tipos de biomas ou regiões econômicas. É importante destacar, portanto, que a pluralidade das cidades-gêmeas se constitui como um desafio para a elaboração de leis de âmbito nacional que visam o fomento do seu desenvolvimento.

Estudiosos da fronteira têm usado, com muita frequência, as cidades-gêmeas como alicerce de suas pesquisas (SILVA; OLIVEIRA, 2008). Por meio do estudo destas cidades é possível perceber que são elas onde melhor são esboçadas as interações das sociedades transfronteiriças e também onde as assimetrias e simetrias entre sistemas territoriais nacionais e internacionais são mais visíveis (MACHADO et al., 2005), permitindo a ocorrência de economias de arbitragem e o estabelecimento de uma relação de complementariedade dos serviços urbanos.

As conexões viárias, como se sabe, desempenham um papel crucial no estabelecimento, intensificação e direção dos fluxos. Algumas das cidades-gêmeas são separadas fisicamente pela existência de um rio. Contudo, nem mesmo a existência de notáveis obstáculos naturais impedem as articulações dos fluxos internacionais realizados pelas cidades-gêmeas.

Neste artigo, como anunciado na introdução, as cidades-gêmeas da região norte terão o seu papel articulador do comércio internacional avaliado. A região brasileira em questão possui oito cidades-gêmeas, a saber: Guajará-Mirim-RO, Epitaciolândia-AC, Brasiléia-AC, Assis Brasil-AC, Tabatinga-AM, Pacaraima-RR, Bonfim-RR e Oiapoque-AP. Anteriormente à análise dos dados de exportação e importação protagonizados por estas cidades, se faz necessário discutir as políticas governamentais que incidem sobre as mesmas. Dentre os oito municípios que abrigam as cidades- 
gêmeas e que serão avaliados neste trabalho, desfrutam da legislação das ALC cinco deles. A saber: Guajará-Mirim-RO, Epitaciolândia-AC, Brasiléia-AC, Tabatinga-AM e Bonfim-RR.

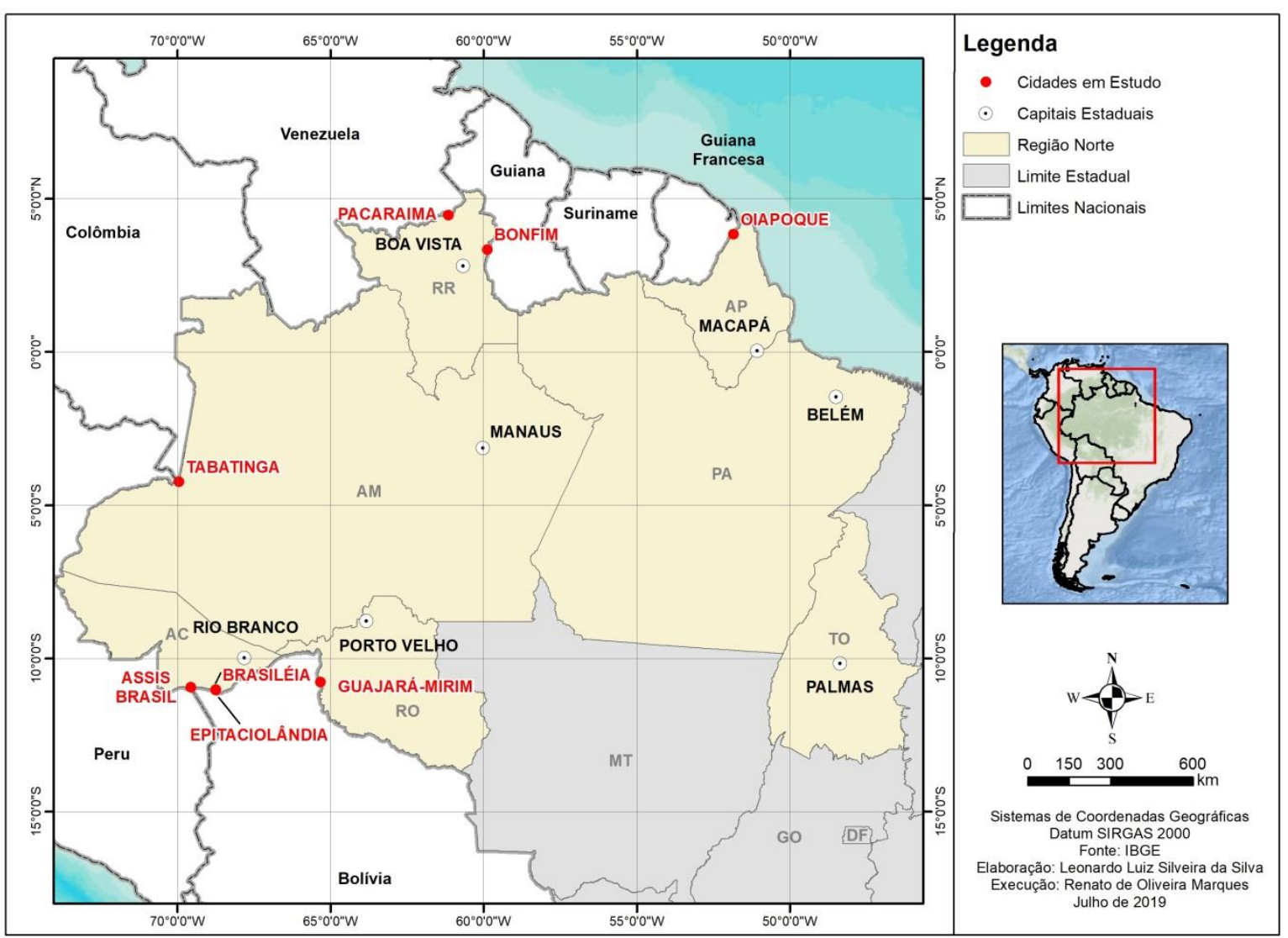

Figura 1 - As cidades-gêmeas do norte brasileiro.

\section{AS POLÍTICAS TERRITORIAIS DA FRONTEIRA BRASILEIRA}

A fundação de cidades-vigilantes junto ao limite internacional é um ato primário de reconhecimento do valor estratégico da fronteira. A definição da existência e extensão da faixa de fronteira sofistica o planejamento estratégico do Estado, que tem no estabelecimento de politicas territoriais especiais uma de suas expressões. Inúmeras políticas, geralmente apresentadas como “programas”, são estabelecidas nas áreas de fronteira (EUZÉBIO, 2014). Visam o fomento do desenvolvimento militar, mas também o econômico e o social. No arco norte, em especial, a preocupação com a segurança se destaca.

As desigualdades espaciais olhadas sob as lentes do descompassado desenvolvimento social e econômico são regras e não exceções. Nos países com menor grau de desenvolvimento social e econômico, os abissais desníveis de desenvolvimento regional tem origem bem diversa e apresentam características próprias. Geralmente, nesses países, as áreas especializadas em produtos de exportação, em consequência do investimento de capitais estrangeiros, crescem economicamente 
nos setores atingidos por esses capitais, atraem habitantes, obtêm elevada renda per capita e se distanciam das áreas dedicadas a outras atividades econômicas (ANDRADE, 1977). É neste particular que a Geografia deve se apoiar na História para entender o peso das reminiscências coloniais no arranjo espacial contemporâneo. Definitivamente, sob o julgo colonial, o território brasileiro não potencializou economicamente sua área de fronteira, muito distante de sua base exportadora a serviço da metrópole.

Dentre as tentativas de desenvolver a deprimida área de fronteira destaca-se, no caso brasileiro, o Programa de Desenvolvimento da Faixa de Fronteira (PDFF). O mesmo tem como objetivo principal promover o desenvolvimento por meio de sua estruturação física, social e produtiva, com ênfase na ativação das potencialidades locais e na articulação com outros países da América do Sul (BRASIL, 2009, p.12). Há uma crença, dos gestores do programa, de que os atores locais, uma vez fortalecidos, vão protagonizar "o processo de desenvolvimento endógeno e sustentável, resultando no fortalecimento de novos eixos dinâmicos da economia" (BRASIL, 2009, p.14).

Tabela 1 - Características dos municípios contemplados pela PDFF.

\begin{tabular}{cc}
\hline $\begin{array}{c}\text { Tipo de Município contemplado } \\
\text { pela PDFF }\end{array}$ & Característica \\
\hline & $\begin{array}{c}\text { O território do município faz limite com o país vizinho e } \\
\text { sua sede se localiza no limite internacional, podendo ou } \\
\text { não apresentar uma conurbação ou semiconurbação com } \\
\text { uma localidade do país vizinho (cidades-gêmeas). } \\
\text { O território do município faz divisa com o país vizinho, } \\
\text { mas cuja sede não se situa no limite internacional. } \\
\text { O território do município faz divisa com o país vizinho, } \\
\text { mas cuja sede está fora da Faixa de Fronteira. } \\
\text { O município não faz divisa com o país vizinho e a sua } \\
\text { sede situa-se dentro da faixa de fronteira. } \\
\text { O município não faz divisa com o país vizinho, possui } \\
\text { apenas parte do seu território inserido na Faixa de } \\
\text { Fronteira e sua sede municipal situa-se fora da faixa em } \\
\text { Não-Lindeiro }\end{array}$ \\
\hline
\end{tabular}

Fonte: BRASIL (2005), organizado pelos autores.

No ano de 2005, com a publicação da Proposta de Reestruturação do Programa de Desenvolvimento da Faixa de Fronteira (PDFF), uma regionalização foi elaborada tendo como tema a repartição do espaço fronteiriço brasileiro. A partir desta elaboração, surgem arcos e subdivisões. Além disto, as cidades-gêmeas ganharam notoriedade e a ideia de faixa de fronteira passou a incorporar sistematicamente os estudos geopolíticos que versam sobre a política transfronteiriça (Dorfman e França, 2016). 
Tabela 2 - Regiões e suas respectivas Sub-Regiões estabelecidas pelo PDFF.

\begin{tabular}{cc}
\hline Região & Sub-região \\
\hline \multirow{3}{*}{ Arco Norte } & Oiapoque-Tumucumaque \\
Campos do Rio Branco & Parima-Alto Rio Negro \\
& Alto Solimões \\
Alto Juruá & Vale do Acre-Alto Purus \\
Madeira-Mamoré \\
Fronteira do Guaporé \\
Chapada dos Parecis \\
Arco Central \\
\\
\end{tabular}

De todas as políticas territoriais brasileiras, talvez aquela que estabeleça impactos mais contundentes no arranjo das redes e na mudança da realidade espacial da faixa de fronteira seja a política de implantação das Áreas de Livre Comércio (ALCs). As vantagens fiscais se expressam tanto na importação de mercadorias estrangeiras como na aquisição de mercadorias do mercado nacional, produzidas em outras unidades da federação.

A entrada de mercadorias estrangeiras nas ALCs se dá com a isenção do Imposto de Importação sobre produtos industrializados, desde que a mercadoria seja destinada ao consumo e venda no interior dos limites territoriais dos municípios que usufruem dessa legislação especial. As mercadorias adquiridas no mercado nacional podem ser contempladas com o benefício da isenção do ICMS e do IPI. Respeitando lógica similar aos produtos importados, o benefício fiscal das mercadorias nacionais ocorre desde que as mesmas sejam devidamente internadas e destinadas ao mercado interno dos municípios beneficiados. Em recente trabalho de campo à cidade-gêmea de Guajará-Mirim-RO, notou-se que pequenos comerciantes, que não conseguem importar em grandes volumes, colocam em dúvida a permanência das mercadorias internadas na Área de Livre Comércio de Guajará-Mirim (ALCGM). A evasão destas mercadorias uma vez internadas sob o regime das ALCs infligiria a legislação e se constituiria em uma concorrência desleal.

A política territorial das ALCs é capaz de fortalecer economicamente os municípios contemplados. Devido à atuação de grandes empresas monopolistas, em uma análise apriorística, sabe-se que a política das ALCs é capaz de gerar emprego para a faixa de fronteira do território brasileiro. Contudo, são estimuladas atividades extremamente concentradoras de renda, colocandonos defronte a uma reflexão sobre o que seria uma situação de "prosperidade regional". Respostas diversas podem surgir, principalmente guiadas por convicções ideológicas. 
Tabela 3- Municípios brasileiros contemplados pelo regime das ALCs.

\begin{tabular}{ccc}
\hline Cidade & Unidade da Federação & Cidade-Gêmea \\
\hline Boa Vista & Roraima & Não \\
Bonfim & Roraima & Sim \\
Guajará-Mirim & Rondônia & Sim \\
Brasiléia & Acre & Sim \\
Epitaciolândia & Acre & Sim \\
Cruzeiro do Sul & Acre & Não \\
Tabatinga & Amazonas & Sim \\
Macapá & Amapá & Não \\
Santana & Amapá & Não \\
\hline
\end{tabular}

Fonte: SUFRAMA, 2013.

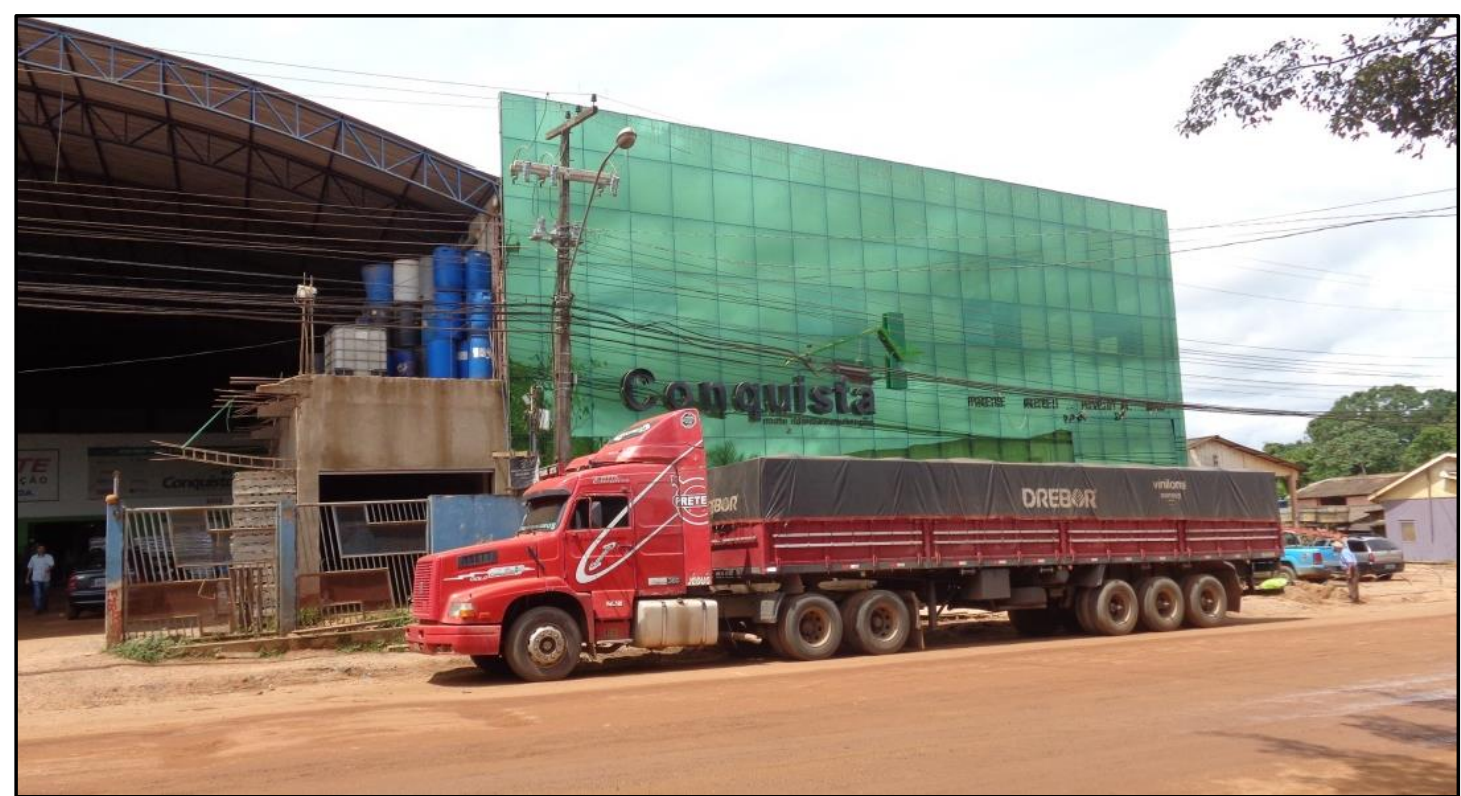

Figura 2 - Estabelecimento comercial instalado na principal avenida de Brasiléia-AC. As cidades-gêmeas contempladas pelo regime das ALCs abrigam grandes empresas que atuam no atacado e varejo. Pela legislação, estas empresas não podem enviar seus produtos para fora dos limites municipais, sendo limitadas a fazer vendas locais.

Fonte: Foto dos autores.

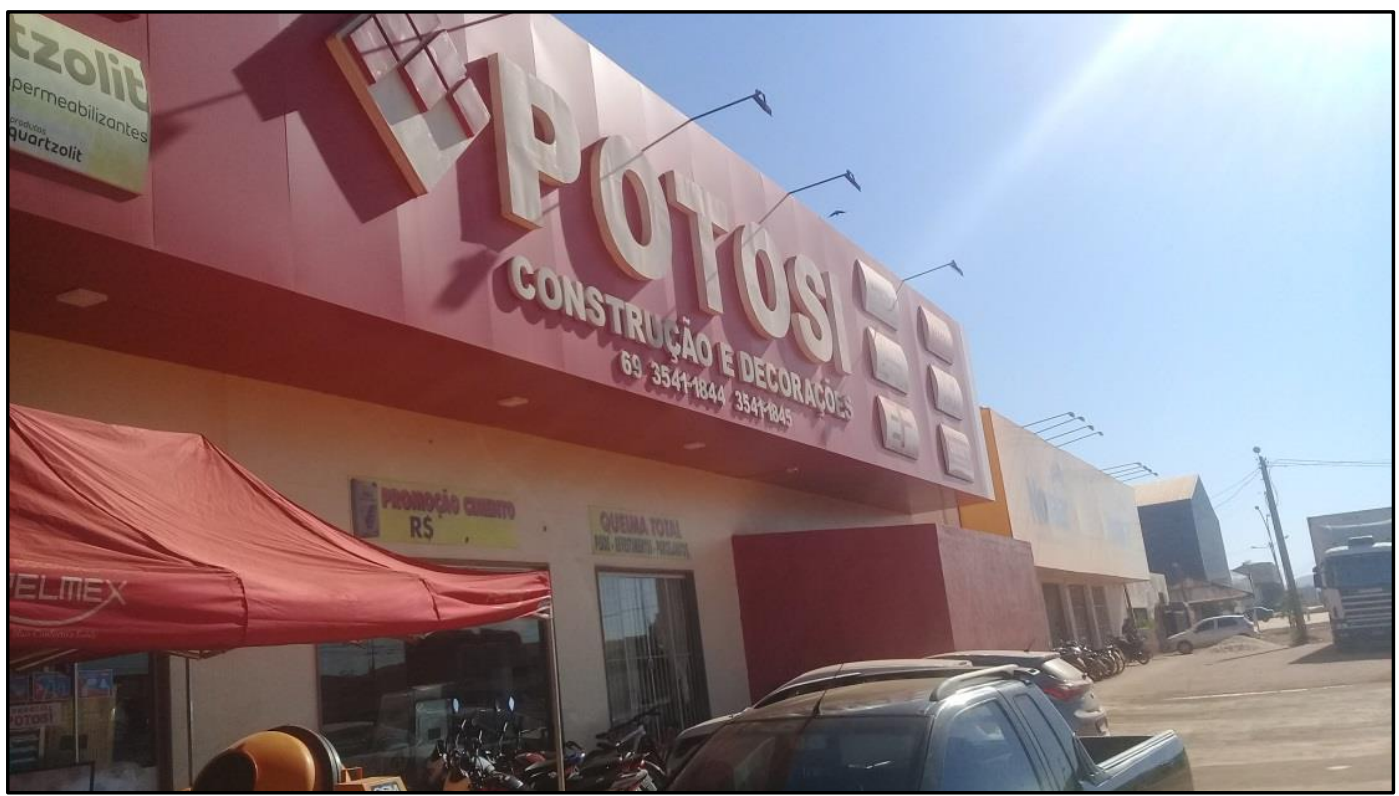

Figura 3 - Estabelecimento comercial instalado na principal avenida de Guajará-Mirim-RO. Atuando no atacado e varejo, este estabelecimento usufrui da legislação da ALC.

Fonte: Foto dos autores, 2019. 


\section{AS IMPORTAÇÕES E AS EXPORTAÇÕES ARTICULADAS PELAS CIDADES- GÊMEAS DA REGIÃO NORTE}

Era de se esperar, pelo caráter lindeiro das cidades-gêmeas, que as mesmas pudessem servir como esplêndidas plataformas de exportação e importação do Brasil. Em uma análise minuciosa dos dados do comércio exterior brasileiro no nível municipal (BRASIL, 2019), verifica-se que as cidades-gêmeas da região norte brasileira, salvo poucas exceções, desempenham papel irrisório na articulação do comércio exterior brasileiro. É adequado que os dados sejam divulgados em nível municipal, visto que a legislação das ALCs privilegiam todo o espaço do município e não somente a área urbana.

Anteriormente à apresentação destes dados, é importante destacar que existe uma força econômica subjacente e de difícil mensuração: a economia informal. Esta força, guiada inclusive pela chamada "economia de arbitragem" (que se aproveita das oscilações cambiais ou do contraste da legislação em área de fronteira para a maximização de lucros nos empreendimentos), não participa dos dados oficiais. Pelo menos no que diz respeito à sua atuação direta, por se tratar de uma movimentação financeira não declarada, a economia informal não contribui para $o$ fortalecimento do poder público por meio do recolhimento de impostos, em um ambiente que já é marcado pela renúncia fiscal devido ao vigor do regime da ALC. Contudo, sabe-se que a economia informal possui o seu valor para as economias domésticas. O afrouxamento da fiscalização, inclusive, pode ser entendido como uma permissividade desejável do poder público, que veriam em sua tolerância uma forma de fortalecer a economia doméstica, ainda que informal.

É importante destacar também que os municípios contemplados pelo regime da ALC não tem suas empresas automaticamente inseridas nas vantagens fiscais previstas pela legislação. Se faz necessário um movimento por parte do empreendedor para o cadastramento de sua empresa no regime, possibilitando que as mercadorias que usufruem das vantagens da renúncia fiscal passem por uma vistoria do SUFRAMA, autarquia que fiscaliza e legaliza os produtos. Este procedimento, inclusive, gerou um neologismo de cunho popular. Fala-se para àquele comerciante que passou pelo procedimento burocrático para a obtenção das vantagens fiscais que as suas mercadorias estão "suframadas". Uma parcela dos comerciantes, sobretudo os microempreendedores, não usufrui do regime das ALCs. Esta questão parece ser explicada em alguns casos pelo baixo capital de giro e pequena movimentação de mercadorias aliado à baixa capacidade de estocagem.

Mesmo quando consideramos o papel destes municípios no conjunto das unidades da federação que os abrigam é difícil falarmos de protagonismo, como consta nos dados da Tabela 5. 
Tabela 4 - Valores de Exportação e Importação dos municípios que abrigam cidades-gêmeas da região norte brasileira em US\$ FOB 2016-2018

\begin{tabular}{|c|c|c|c|c|c|c|}
\hline Município & $\begin{array}{c}\text { Exportação } \\
2016\end{array}$ & $\begin{array}{c}\text { Importação } \\
2016\end{array}$ & $\begin{array}{c}\text { Exportação } \\
2017\end{array}$ & $\begin{array}{c}\text { Importação } \\
2017\end{array}$ & $\begin{array}{c}\text { Exportação } \\
2018\end{array}$ & $\begin{array}{c}\text { Importação } \\
2018\end{array}$ \\
\hline Brasiléia-AC & 7.400 .000 & 438.820 & 4.110 .000 & 724.060 & 7.150 .000 & 314.260 \\
\hline Epitaciolândia-AC & 13.430 .000 & 106.720 & 9.300 .000 & 46.410 & 12.450 .000 & 85.430 \\
\hline Tabatinga-AM & $\begin{array}{c}\text { Não } \\
\text { registrado }\end{array}$ & 80.260 & $\begin{array}{c}\text { não } \\
\text { registrado }\end{array}$ & 75.740 & 9.500 & 94.330 \\
\hline Guajará-Mirim-RO & 54.830 .000 & 305.680 & 67.610 .000 & 233.160 & 35.790 .000 & 1.000 .000 \\
\hline Pacaraima-RR & 693.800 & $\begin{array}{c}\text { não } \\
\text { registrado }\end{array}$ & 243.150 & $\begin{array}{c}\text { não } \\
\text { registrado }\end{array}$ & $\begin{array}{c}\text { não } \\
\text { registrado }\end{array}$ & 10.680 \\
\hline Bonfim-RR & 253.290 & 67.070 & 355.090 & $\begin{array}{l}\text { não } \\
\text { registrado }\end{array}$ & 225.450 & $\begin{array}{c}\text { não } \\
\text { registrado }\end{array}$ \\
\hline Assis Brasil-AC & $\begin{array}{c}\text { não } \\
\text { registrado }\end{array}$ & $\begin{array}{c}\text { não } \\
\text { registrado }\end{array}$ & $\begin{array}{c}\text { não } \\
\text { registrado }\end{array}$ & $\begin{array}{c}\text { não } \\
\text { registrado }\end{array}$ & $\begin{array}{c}\text { não } \\
\text { registrado }\end{array}$ & $\begin{array}{c}\text { não } \\
\text { registrado }\end{array}$ \\
\hline Oiapoque-AP & $\begin{array}{l}\text { não } \\
\text { registrado }\end{array}$ & $\begin{array}{l}\text { não } \\
\text { registrado }\end{array}$ & $\begin{array}{l}\text { não } \\
\text { registrado }\end{array}$ & $\begin{array}{l}\text { não } \\
\text { registrado }\end{array}$ & $\begin{array}{l}\text { não } \\
\text { registrado }\end{array}$ & $\begin{array}{l}\text { não } \\
\text { registrado }\end{array}$ \\
\hline
\end{tabular}

Fonte: Brasil, 2019.

Tabela 5 - Posição das cidades-gêmeas da região norte brasileira no ranking da participação estadual no comércio exterior.

\begin{tabular}{ccc}
\hline Município & $\begin{array}{c}\text { Posição no ranking estadual de } \\
\text { exportações }\end{array}$ & $\begin{array}{c}\text { Posição no ranking estadual de } \\
\text { importações }\end{array}$ \\
\hline Brasiléia-AC & $4^{\circ}$ & $2^{\circ}$ \\
Epitaciolândia-AC & $2^{\text {o }}$ & $4^{\circ}$ \\
Tabatinga-AM & $14^{\text {o }}$ & $9^{\circ}$ \\
Guajará-Mirim-RO & $10^{\circ}$ & $5^{\circ}$ \\
Pacaraima-RR & não exportou & $2^{\text {o }}$ \\
Bonfim-RR & $4^{\circ}$ & não importou \\
Assis Brasil-AC & não exportou & não importou \\
Oiapoque-AP & não exportou & não importou \\
\hline
\end{tabular}

Fonte: Brasil, 2019.

Há de se destacar que, do ponto de vista demográfico, as cidades-gêmeas da região norte brasileira são pouco populosas. Muitos dos seus dados socioeconômicos precisam ser analisados fora da lógica dos números absolutos, frente à irrisória participação das mesmas no conjunto global dos territórios nos quais estão inseridas, seja no nível estadual ou federal.

$\mathrm{Na}$ maioria das cidades-gêmeas que realizam importações e exportações, verificamos a concentração das operações comerciais em um só produto, situação já esperada mediante o pequeno volume negociado. Dentre as cidades contempladas por este artigo, àquela que apresenta a pauta de exportações mais diversificada é justamente a que negocia o maior volume: a cidade-gêmea de Guajará-Mirim. A cidade rondoniense em questão apresenta o óleo de soja como o principal item exportado, alcançando $11 \%$ do valor total das exportações. Em contrapartida, Guajará-Mirim, por pouco importar, apresenta um rol muito menor de produtos em sua pauta de importação frente à de 
exportação. Nesta tabela, as colônias e os perfumes assumem um protagonismo das importações, atingindo um patamar de 57\% do total dos valores importados, em dados de 2018 (BRASIL, 2019). Estas observações aqui tratadas são endossadas pelos dados apresentados pela tabela 7.

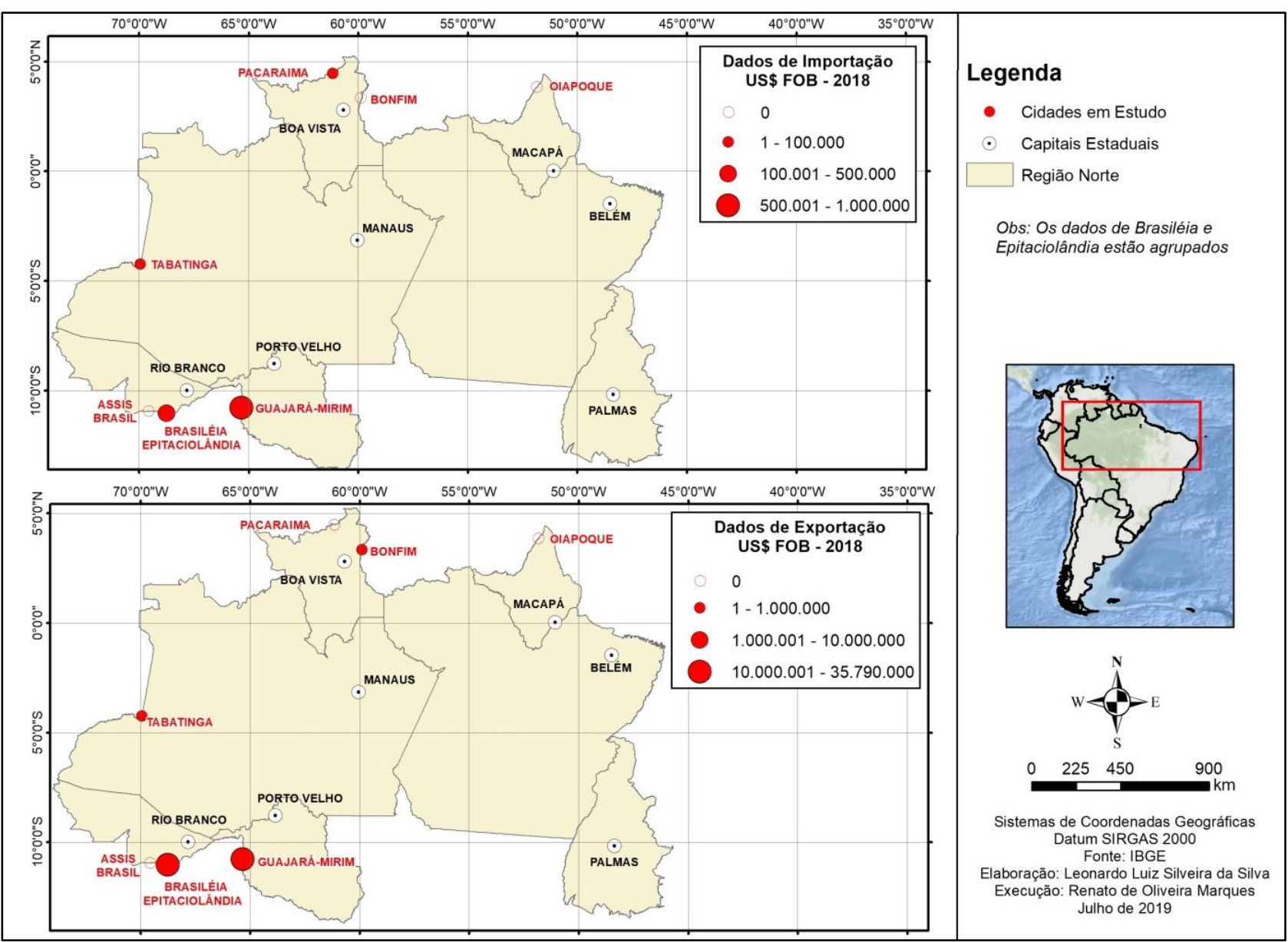

Figura 4 - Valores de exportação e importação das cidades-gêmeas do norte do Brasil no ano de 2018 em US\$ FOB.

Tabela 6 - População urbana e rural dos municípios que abrigam as cidades-gêmeas da região norte brasileira segundo censo 2010

\begin{tabular}{cccc}
\hline Município & População urbana & População rural & População total \\
\hline Brasiléia-AC & 14.257 & 7.141 & 21.398 \\
Epitaciolândia-AC & 10.618 & 4.482 & 15.100 \\
Tabatinga-AM & 36.355 & 15.917 & 52.272 \\
Guajará-Mirim-RO & 35.207 & 6.449 & 41.656 \\
Pacaraima-RR & 4.514 & 5.919 & 10.433 \\
Bonfim-RR & 7.232 & 3.711 & 10.943 \\
Assis Brasil-AC & 3.700 & 2.372 & 6.072 \\
Oiapoque-AP & 13.852 & 6.657 & 20.509 \\
\hline
\end{tabular}

Fonte: IBGE, 2019. 
Tabela 7 - Principais produtos exportados e importados pelas cidades-gêmeas da região norte brasileira em 2018 e sua participação relativa.

\begin{tabular}{|c|c|c|c|c|}
\hline Município & $\begin{array}{c}\text { Principal } \\
\text { produto } \\
\text { exportado }(2018)\end{array}$ & $\begin{array}{c}\text { Participação \% } \\
\text { no total das } \\
\text { exportações } \\
(2018)\end{array}$ & $\begin{array}{c}\text { Principal } \\
\text { produto } \\
\text { importado }(2018)\end{array}$ & $\begin{array}{c}\text { Participação \% } \\
\text { no total das } \\
\text { importações } \\
(\mathbf{2 0 1 8 )}\end{array}$ \\
\hline Brasiléia-AC & Cocos e castanha & 87 & $\begin{array}{l}\text { Polímeros de } \\
\text { cloreto de vinilo }\end{array}$ & 64 \\
\hline Epitaciolândia-AC & $\begin{array}{c}\text { Carnes e miudezas } \\
\text { comestíveis de } \\
\text { aves }\end{array}$ & 24 & $\begin{array}{l}\text { Celulose e seus } \\
\text { derivados } \\
\text { químicos }\end{array}$ & 39 \\
\hline Tabatinga-AM & $\begin{array}{l}\text { Iates e barcos de } \\
\text { recreação }\end{array}$ & 100 & $\begin{array}{l}\text { Partes de } \\
\text { máquinas ou } \\
\text { aparelhos }\end{array}$ & 91 \\
\hline Guajará-Mirim-RO & Óleo de Soja & 11 & $\begin{array}{l}\text { Perfumes e } \\
\text { colônias }\end{array}$ & 57 \\
\hline Pacaraima-RR & Não registrado & Não registrado & $\begin{array}{l}\text { Perfis de ferro ou } \\
\text { aço não ligados }\end{array}$ & 92 \\
\hline Bonfim-RR & $\begin{array}{l}\text { Gás de petróleo e } \\
\text { outros } \\
\text { hidrocarbonetos }\end{array}$ & 93 & Não re & trado \\
\hline Assis Brasil-AC & \multirow{2}{*}{\multicolumn{4}{|c|}{$\begin{array}{l}\text { Não registrado } \\
\text { Não registrado }\end{array}$}} \\
\hline Oiapoque-AP & & & & \\
\hline
\end{tabular}

Fonte: Brasil, 2019.

Outra marca característica do comércio protagonizado pelas cidades-gêmeas da região norte brasileira é o fato das exportações estarem centradas nos países lindeiros ou geograficamente próximos. O mesmo não ocorre com as importações, centradas em países do além-mar. Principalmente no que diz respeito às importações, tanto a origem quanto a participação da mesma no total importado podem oscilar fortemente de um ano para outro. Este cenário se explica pelo fato das importações serem ainda mais irrisórias do que as exportações protagonizadas pelas cidadesgêmeas avaliadas. O caráter das importações é o de "compras pontuais".

Tabela 8 - Destino das exportações, origem das importações e participação nos totais exportados e importados pelas cidades-gêmeas da região norte brasileira

\begin{tabular}{ccccc}
\hline $\begin{array}{c}\text { Município } \\
\text { Principal destino } \\
\text { das exportações }\end{array}$ & $\begin{array}{c}\text { Participação \% } \\
\text { do destino no } \\
\text { total exportado }\end{array}$ & $\begin{array}{c}\text { Principal origem } \\
\text { das importações }\end{array}$ & $\begin{array}{c}\text { Participação \% } \\
\text { da origem no } \\
\text { total importado }\end{array}$ \\
$\begin{array}{c}\text { Brasiléia-AC } \\
\text { Epitaciolândia-AC }\end{array}$ & Peru & 62 & China & 87 \\
Tabatinga-AM & Colômbia & 70 & China & 80 \\
Guajará-Mirim-RO & Bolívia & 100 & Tailândia & 100 \\
Pacaraima-RR & Não exportou & Venezuela & 31 \\
Bonfim-RR & Guiana & 100 & Não importou \\
Assis Brasil-AC & Não exportou & Não importou \\
Oiapoque-AP & Não exportou & Não importou \\
\hline
\end{tabular}

Fonte: Brasil, 2019. 
A partir da tabela até aqui desenhado, lançamos a hipótese das capitais dos respectivos estados que abrigam as cidades-gêmeas aqui analisadas exercerem um papel aglutinador do comércio exterior. Considerando o arranjo logístico que beneficia as capitais em detrimento das periferias estaduais, cogitamos a possibilidade das primeiras agirem como um centro de gravidade da produção econômica periférica, atraindo o fluxo daquilo que é produzido em suas cercanias para o seu centro, de onde ocorreria a dispersão das mercadorias via exportação. Da mesma forma poderia atuar a importação, sendo trazidas do exterior para as capitais, de onde o importador poderia acessá-las e conduzi-las ao espaço periférico. Nesse sentido, o registro estatístico mascararia as importações e exportações periféricas, inflando os registros dos grandes centros.

Tabela 9 - Exportação e Importação das capitais dos estados que abrigam cidades-gêmeas da região norte brasileira em milhões de US\$ FOB.

\begin{tabular}{ccccc}
\hline Capital & Exportação 2018 & $\begin{array}{c}\text { Média 2009-2018 } \\
(\mathbf{1 0} \text { anos })\end{array}$ & Importação 2018 & $\begin{array}{c}\text { Média 2009-2018 } \\
(\mathbf{1 0} \text { anos })\end{array}$ \\
\hline Porto Velho & 80,77 & 75,1 & 828,66 & 509,87 \\
Macapá & 21,41 & 12,32 & 148,83 & 49,79 \\
Manaus & 595,18 & 839,42 & $9.919,78$ & 10.445 \\
Rio Branco & 9,13 & 5,95 & 2,18 & 3,25 \\
Boa Vista & 16,61 & 12,74 & 10,53 & 8,31 \\
\hline
\end{tabular}

Fonte: Brasil, 2019.

Percebemos, contudo, que cada caso tem a sua particularidade. As capitais da região norte brasileira estão inseridas em estados com características econômicas distintas. Enquanto ManausAM é um expoente do comércio exterior brasileiro, Rio Branco-AC apresenta papel irrisório. Considerando o grupo dos estados que abrigam as cidades-gêmeas da região norte, podemos dividilos em quatro estratos no que diz respeito a sua participação no comércio exterior:

- O primeiro estrato composto por Acre e Roraima. Os dois estados negociam volumes irrisórios comparativamente aos demais estados da região norte avaliados, não alcançando a cifra anual de 40 milhões de US\$ FOB para nenhuma operação do comércio exterior;

- O segundo estrato é composto pelo Amapá, que, em dados de 2018, movimentou pouco mais de 450 milhões de US\$ FOB na soma de suas exportações e importações;

- O terceiro estrato é composto por Rondônia, que movimentou pouco mais de 2 bilhões de US\$ FOB no seu comércio exterior no ano de 2018;

- Finalmente, o quarto estrato é composto pelo Amazonas, que movimentou mais de 10 bilhões de US\$ FOB em exportações e importações. Deste montante, cerca de $94 \%$ foi composto por importações. Sabe-se que a Zona Franca de Manaus especializou-se na montagem de elétricos e eletrônicos a partir da importação de componentes livres de taxação. 
Faz-se necessário, diante estas diferenças, a realização de uma breve análise particularizada das oito cidades-gêmeas. Brasiléia e Epitaciolândia serão apresentadas conjuntamente, à medida que as duas cidades-gêmeas formam uma tríplice conurbação que as une com a cidade boliviana de Cobija, capital do departamento de Pando.

\section{BREVE ANÁLISE DO PAPEL DAS CIDADES-GÊMEAS DA REGIÃO NORTE BRASILEIRA NO COMÉRCIO EXTERIOR BRASILEIRO}

A) Guajará-Mirim-RO: A cidade-gêmea rondoniense está localizada deslocada do principal eixo de desenvolvimento do estado, que é a BR-364, que liga Cuiabá-MT a Rio Branco-AC, passando por Porto Velho-RO. Apesar disto, destacou-se com a exportação de 67 milhões de US\$ FOB em 2017 e 35 milhões em 2018. Trata-se, por isso, da cidade-gêmea da região norte brasileira que movimenta o maior volume financeiro no comércio exterior. Exibe, contudo, valores de importações irrisórios, que não tem superado os 100.000 US\$ FOB nos últimos três anos. Tendo a quase totalidade de suas exportações direcionadas à Bolívia, a posição urbana de Guajará-Mirim-RO é um dos seus trunfos. Ainda que exiba dificuldades nas conexões viárias (conecta-se a Porto Velho por uma via secundária) que acarretam em fretes onerosos, beneficia-se da incipiente industrialização do departamento boliviano do Beni, território ao qual é vizinho. Diariamente, um volume significativo de mercadorias atravessa o rio Mamoré empilhadas em balsas rumo à Bolívia. Podemos dizer que os tentáculos econômicos brasileiros alcançam áreas significativas do departamento de Beni com grande eficácia, disputando o seu mercado com as redes econômicas domésticas bolivianas. É importante destacar que Guajará-Mirim-RO está inserida em um estado em que a capital não é o principal protagonista do comércio exterior. Com um grande número de municípios com exportações expressivas para o contexto regional, o estado de Rondônia exibe o município de Vilhena-RO como o principal exportador, com $22 \%$ do valor (US\$ FOB) de toda a exportação estadual registrada no ano de 2018 (BRASIL, 2019). Assim, Rondônia apresenta-se como um estado que pode surpreender quanto ao levantamento do seu comércio exterior: nem a capital e nem o município contemplado pelo regime da ALC (Guajará-Mirim-RO) são os principais destaques. Vilhena-RO, exportando principalmente carne bovina e soja, tem se mantido em um patamar acima de 200 milhões de US\$ FOB de exportação de 2012 a 2018. Mesmo assim, é notável a força do comércio local de Guajará-Mirim-RO, que se aproveita da ALC para dinamizar o seu mercado doméstico. O regime da ALC em Guajará-Mirim-RO, juntamente com o contexto regional boliviano, ajudam a explicar os valores expressivos de exportação. A importação irrisória municipal, já comentada, tem o caráter de "compras pontuais" e não encontra no país vizinho (Bolívia) a sua origem. 


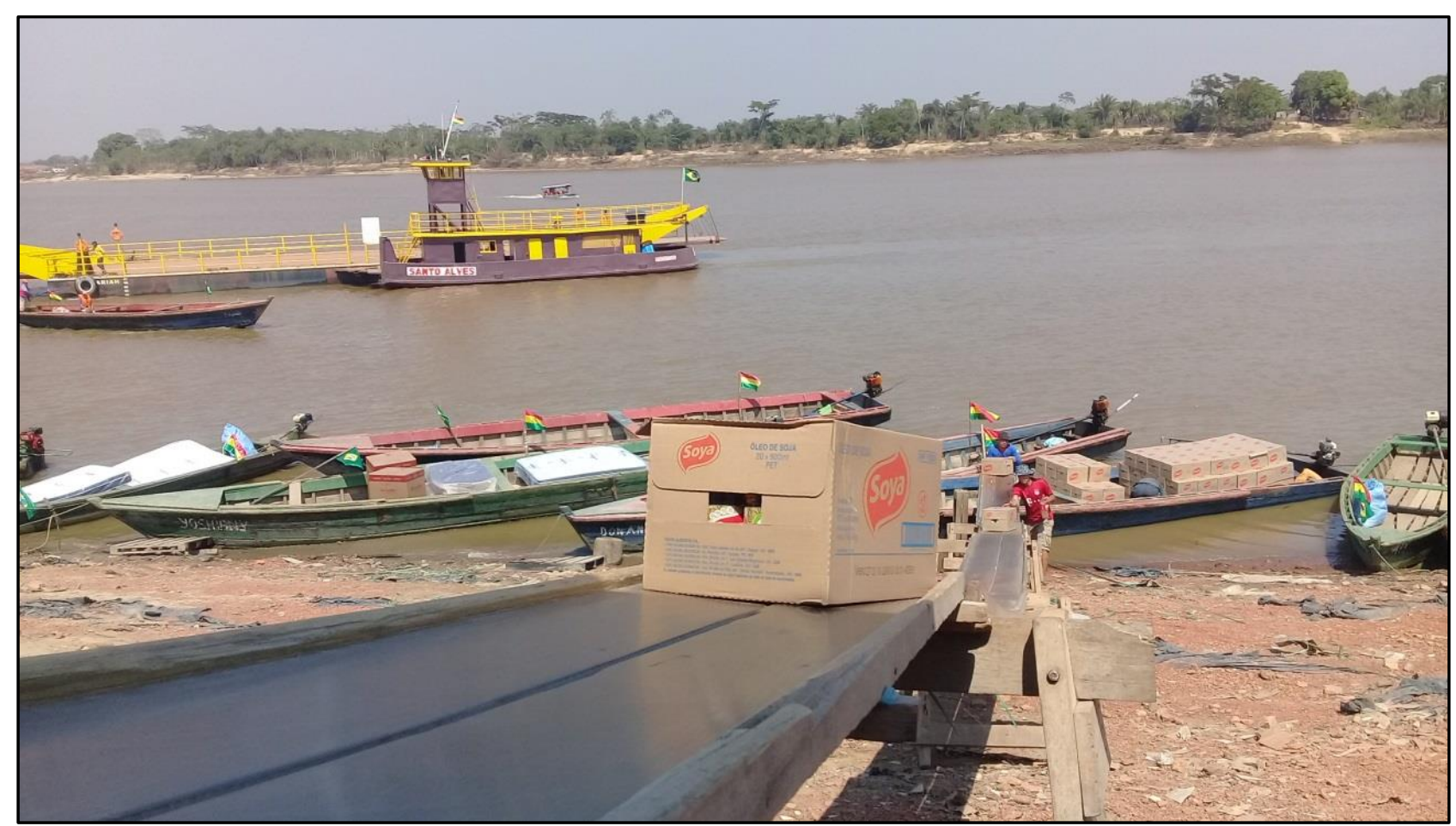

Figura 5 - Carregamento das balsas no porto de Guajará-Mirim-RO visando à travessia do rio Mamoré rumo à Guayaramerín-BOL. Fonte: Foto dos autores.

B) Brasiléia-AC e Epitaciolândia-AC: Analisando os dados de exportação aglutinados dos dois municípios que possuem cidades-gêmeas conurbadas, temos um resultado que se aproxima aos valores exportados por Guajará-Mirim-RO (20 milhões de US\$ FOB ante 35 milhões registrados em 2018). As importações, também irrisórias, não superaram 800.000 US\$ FOB no período de 2016 a 2018 (BRASIL, 2019), apresentando-se, assim como se viu em Guajará-Mirim-RO, um quadro assimétrico envolvendo exportações e importações. Vistas como uma só entidade espacial, Brasiléia-AC e Epitaciolândia-AC exportaram cerca de $45 \%$ de todos os valores exportados pelo estado, deixando para trás a capital Rio Branco-AC, que exportou cerca de $20 \%$ do total global. Além da Bolívia, os dois municípios do Acre estendem a carta de clientela ao Peru, fato explicado pela posição urbana das cidades no contexto regional. Cortados pela Carretera Interoceânica (BR317), os centros urbanos dos dois municípios distam $115 \mathrm{~km}$ da cidade peruana mais próxima, que é Iñapari. Apesar dos valores expressivos de exportação do ponto de vista regional, Brasiléia-AC e Epitaciolândia-AC possuem suas pautas de exportação concentrada em poucos produtos, fato mais notável no primeiro município, que do total de suas exportações registrou $87 \%$ centrados em cocos e castanha em dados de 2018 (BRASIL, 2019).

C) Assis Brasil-AC: A cidade acreana, situada junto ao tríplice limite entre o Brasil, a Bolívia e o Peru, contava com 3.700 habitantes em sua zona urbana e não mais que 7.000 habitantes em toda a área municipal em 2010, de acordo com os dados do Censo. Apesar de sua posição privilegiada de acesso ao Oceano Pacífico por meio da Carretera Interoceânica, trata-se de um espaço subpovoado, 
dotado de cifras econômicas irrelevantes. Não se trata de um município que desfruta do regime das ALCs. Não é de se surpreender que não conste registros de exportação ou importação realizados pelo município.

D) Tabatinga-AM: Situada junto ao tríplice limite entre Brasil, Peru e Colômbia, o município faz intermediações comerciais irrisórias. São exportações e importações pontuais que não superaram a cifra de 100.000 US\$ FOB no período de 2016 a 2018 (BRASIL, 2019), tendo como principal parceiro a Colômbia. A cidade amazonense é beneficiada pelo regime das ALCs, mas este fato pouco colabora para o estabelecimento de fluxos econômicos internacionais registrados pela receita brasileira. Há de se perceber que a zona lindeira peruana, junto ao sítio urbano de Tabatinga-AM, é despovoada. Em contrapartida, a cidade colombiana de Letícia forma uma conurbação com Tabatinga-AM. A despeito da rica rede de drenagem regional, característica marcante da Amazônia ocidental, Letícia e Tabatinga-AM possuem seu sítio urbano encravado em um trecho da fronteira seca entre Brasil e Colômbia, característica que favorece as trocas formais e informais. Dada as relações de complementariedade urbana típicas de uma conurbação, é provável que os dados oficiais não mensure parcela importante dos fluxos econômicos interurbanos entre Letícia e Tabatinga-AM.

E) Pacaraima-RR: Das oito cidades-gêmeas contempladas neste trabalho, Pacaraima-RR é a segunda menos populosa. Em sua área urbana não soma 5.000 habitantes, em dados do Censo 2010. Apesar de Pacaraima-RR exibir o sítio urbano da sede municipal lindeiro à Venezuela, não se constitui em uma conurbação urbana. Santa Helena de Uiarén, cidade venezuelana mais próxima, dista 17 km. No período de 2016 a 2018, Pacaraima realizou operações de exportação e importação pontuais, intervaladas e irrisórias, não superando os 700.000 US\$ FOB nem mesmo no momento de um pico exportador, no ano de 2016. Entre 2011 e 2015 não se verificou nenhuma exportação e, tampouco, exportação por parte do município roraimense. Como poderíamos supor devida à sua posição urbana, Pacaraima-RR tem tido a Venezuela como seu parceiro comercial exclusivo. Verifica-se o translado de venezuelanos em busca de produtos brasileiros e, também, cidadãos brasileiros atravessam o limite internacional em busca de gasolina em um preço mais acessível do que o praticado no mercado doméstico. Pacaraima-RR não usufrui do regime das ALCs.

F) Bonfim-RR: Esta cidade-gêmea roraimense possui características muito semelhantes a de Pacaraima-RR no que tange ao seu comércio exterior e sua demografia. Realizou exportações e importações pontuais, interrompidas e irrisórias no período de 2016 a 2018, não movimentando valores anuais maiores do que 400.000 US\$ FOB na soma das operações de comércio exterior 
(BRASIL, 2019). Com o sítio urbano lindeiro à Guiana, Bonfim-RR tem tido neste país o seu parceiro comercial exclusivo. Bonfim-RR, contrariamente à Pacaraima-RR, desfruta do regime das ALCs. Contudo, o vigor da regulamentação das ALCs parece não modificar a realidade bonfinense. Lethem, cidade guianense vizinha à Bonfim-RR, está mal integrada às redes viárias e econômicas do seu país, o que dificulta a penetração do dinamismo estrangeiro nas bordas territoriais brasileiras.

G) Oiapoque-AP: Situado no extremo norte brasileiro, o município abriga cidade homônima que não usufrui do regime das ALCs. Apesar de sua posição lindeira (seu sítio jaz junto ao limite com a Guiana Francesa, próximo à cidade de Saint Georges do Oiapoque) o município amapaense não registrou importações ou exportações no período 2016-2018 (BRASIL, 2019). Demograficamente, Oiapoque-AP é mais expressiva do que outras cidades-gêmeas do norte do Brasil que realizam exportações e importações (ainda que irrisórias). Registrou no censo 2010 cerca de 14.000 habitantes no núcleo urbano e 20.000 no total municipal. A fronteira franco-brasileira apresenta um baixo nível de integração socioeconômica, como é sabido pela dificuldade exibida pela travessia da ponte sobre o rio Oiapoque, que une os dois países. Veículos brasileiros pagam taxas altíssimas para adentrar no território ultramarino francês, fazendo da ponte, que deveria servir como marco da integração, um elefante branco. Este rigor talvez explique a inexistência do comércio exterior de Oiapoque-AP.

\section{CONSIDERAÇÕES FINAIS}

Por meio da análise da tabela das exportações e importações protagonizados pelas oito cidades-gêmeas da região norte brasileira (apresentados por meio dos dados municipais), concluímos que, a despeito de sua posição urbana junto ao limite do território nacional, as mesmas exercem um papel irrisório no comércio exterior brasileiro. É importante lembrar que, a despeito de sua posição urbana privilegiada (devido o potencial de articular relações internacionais), as oito cidades gêmeas são de pequeno porte, o que restringe o seu mercado consumidor e o número de empreendedores dispostos a exportar e, principalmente, importar (de acordo com o censo 2010, nenhuma das cidades-gêmeas da região norte possui mais do que 40.000 habitantes). Como maiores exemplos, Assis Brasil-AC, Pacaraima-RR e Bonfim-RR são municípios que possuem em seu distrito-sede menos do que 8.000 habitantes segundo os dados do censo 2010.

Guajará-Mirim-RO, Brasiléia-AC e Epitaciolândia-AC, por sua vez, se apresentam como exceções quando analisamos as exportações. Estas três cidades exportam valores que estão acima da expectativa do seu tamanho, tendo como clientes principais o Peru e a Bolívia, que são países mais próximos. Contudo, quando analisamos as importações, registramos que não há exceção: quando 
ocorre (algumas das cidades-gêmeas não registraram) são valores irrisórios que não superam 1 milhão de US\$ FOB anuais. Se por um lado a posição urbana destas cidades-gêmeas se apresenta como um trunfo às relações exteriores, por outro, se mostra um desafio: situadas na periferia territorial brasileira, mal assistidas pelas redes de transporte, muitas destas cidades possuem custo de frete muito alto, o que dificulta as importações.

Há de se destacar que parcela importante dos fluxos de mercadorias transfronteiriças são articulados pelas migrações pendulares. Bolivianos, peruanos, venezuelanos e guianenses realizam compras diárias visitando as cidades-gêmeas brasileiras. Da mesma forma, brasileiros também atravessam a fronteira e consomem nas cidades estrangeiras vizinhas. É importante lembrar que o arranjo destes fluxos transfronteiriços locais e quiçá regionais é extremamente sensível às oscilações cambiais. Em certos momentos (real valorizado) são os brasileiros que invadem os mercados de Cobija, Guayaramerín, Letícia, Santa Helena de Uiarén e Lethem; em outros momentos, de desvalorização do real, é o estrangeiro que maciçamente busca o mercado brasileiro. Estes dados produzidos pelo comércio articulado pelas migrações pendulares não entram nas estatísticas comerciais e substanciam de forma significativa a economia local.

Cinco das oito cidades-gêmeas analisadas usufruem do regime das ALCs. Apesar disso, as vantagens não se mostram tão decisivas para mudar a realidade do comércio exterior protagonizado por estes centros urbanos lindeiros. Sabe-se que o regime fortalece economicamente as cidades e os municípios, permitindo a instalação de grandes redes atacadistas e varejistas. Esta, contudo, os benefícios não são tão visíveis para a cidade de Bonfim-RR, que é o menor centro urbano beneficiado pela ALC. Do ponto de vista prático apresentam-se como constrangimentos aos importadores:

- os períodos de desvalorização do real, que encarece as importações;

- mercado consumidor municipal restrito;

- a necessidade da mercadoria importada, nos termos da legislação, ser destinada ao consumo interno municipal (a mercadoria não pode ser enviada a um município vizinho, por exemplo. $\mathrm{O}$ potencial comprador precisa se deslocar até o município que abriga a cidade-gêmea para acessar a mercadoria);

- o fato das pequenas compras não serem muito vantajosas devido ao custo proporcional do frete;

- os altos custos dos fretes propriamente ditos;

Destacamos ainda que, neste artigo, foi analisado somente a capacidade exportadora e importadora dos municípios da região norte brasileira que abrigam as cidades-gêmeas. Estes registros são produzidos a partir de exportadores e importadores domiciliados nos municípios em 
questão. Outra questão, não investigada neste artigo, é a intermediação destas cidades-gêmeas a partir da exportação e importação por via terrestre ou fluvial advinda de empresas domiciliadas em outros municípios. O percurso do fluxo exportador e importador pode colaborar sobremaneira para o valor da posição urbana das cidades-gêmeas, que são importantes nós territorializadores dos confins brasileiros.

\section{REFERÊNCIAS}

ABINZANO, R. C. Las Regiones de frontera: espacios complejos de la resistência global. In: OLIVEIRA, T. C. M. (Org.) Territórios sem limites: estudos sobre fronteiras. Campo Grande: UFMS, 2005. p. 113-130.

ANDRADE, M. C. Espaço, polarização e desenvolvimento. São Paulo: Grijalbo, 1977. 120Pp.

BADIE, B. Um mundo sem soberania: os Estados entre o artifício e a responsabilidade. 1. ed. Lisboa: Instituto Piaget, 1999. 326p.

BRASIL. Constituição Federal. Cap.II, Art.20, alínea XI, parágrafo II, 1988.

BRASIL. Ministério da Integração Nacional/Secretaria de Programas Regionais/ Programa de Desenvolvimento da Faixa de Fronteira. Proposta de Reestruturação do Programa de Desenvolvimento da Faixa de Fronteira. Brasília: Ministério da Integração Nacional, 2005.

BRASIL. Ministério da Integração Nacional/Secretaria de Programas Regionais/ Programa de Desenvolvimento da Faixa de Fronteira. Faixa de Fronteira: Programa de Desenvolvimento da Faixa de Fronteira. Brasília: Ministério da Integração Nacional, 2009.

BRASIL. Secretaria de Comércio Exterior. Brasília: comércio exterior, dados municipais. 2019.

BRUNET-JAILLY, E. Power, Politics and Governance of Borderlands. In: GILLES, P. Theorizing borders through analyses of power relationships. Pie Peter Lang, 2012.

CAIRO CAROU, H. Territorialidad e fronteras del estado-nación: las condiciones de la politica en un mundo fragmentado. Politica e Sociedad, Madrid, n. 36, p. 29-38, 2001.

CAMPOS, H. Á. O papel estratégico de cidades gêmeas no controle de mercadorias em regiões de fronteira no contexto do Mercosul: Uruguaiana (BR) e Pasos de Los Libres (AR). Revista Redes, Santa Cruz do Sul, v. 22, n. 1, p. 56-73, 2017.

COELHO, K. N. B. O planejamento urbano regional e a sua importância para as cidades de fronteira. In: ENCONTRO NACIONAL DA ASSOCIAÇÃO NACIONAL DE PÓSGRADUAÇÃO E PESQUISA EM PLANEJAMENTO URBANO E REGINAL. 15., Recife. Anais... Recife: ENAMPUR, 2013. p. 1-12.

DORFMAN, A.; FRANÇA, A. B. C. Estudos fronteiriços no Brasil: uma geografia da produção científica. In: SILVA, A. C. P. (Org.). Geografia Política, Geopolítica e Gestão do território: racionalidades e práticas em múltiplas escalas. Rio de Janeiro: Gramma, 2016. 
EUZÉBIO, E. F. A porosidade territorial da fronteira da Amazônia: as cidades gêmeas de Tabatinga(Brasil) e Letícia (Colômbia). Bogotá: Cuadernos de Geografia - Revista Colombiana de Geografía, Bogotá, v. 23, n. 1, p. 109-124, 2014.

HATALEY, T.; LEUPRECHT, C. Determinants of cross-border cooperation. Jornal of Bordelands studies, v. 33, n. 3, p. 317-328, 2018.

IBGE. Instituto Brasileiro de Geografia e Estatística. Censo 2010.

MACEDO, D. A. Fronteira Brasil-Bolívia em Mato Grosso: segurança pública, desenvolvimento social, e a construção da identidade nacional. RBED, v. 4, n. 2, p. 219, 239, 2007.

MACHADO, L. O. Limites e Fronteiras: da alta diplomacia aos circuitos da ilegalidade. Revista Território, Rio de Janeiro, v. 5, n. 8, p. 7-23, 2000.

MACHADO, L. O.; HAESBAERT, R.; RIBEIRO, L. P.; STEIMAN, R.; PEITER, P. C.; NOVAES, A. R. O desenvolvimento da faixa de fronteira: uma proposta conceitual-metodológica. In: OLIVEIRA, T.C.M. (Org.). Território sem limites: estudo sobre as fronteiras. Campo Grande: UFMS, 2005. p. 87-122.

MATTOS, C. M. Geopolítica e Teoria de Fronteiras. 1. ed. Rio de Janeiro: Biblioteca do Exército, 1990. 116p.

MORAES, A. C. R. Território e História no Brasil. 1. ed. São Paulo, Annablume, 2005. 154p.

NEWMAN, D.; PAASI, A. Fences and neighbours in the postmodern world: boundaries narratives in Political Geography. Progress in Human Geography, v. 22, n. 2, p. 186-207, 1998.

NEWMAN, D. On Borders and Power: a Theoretical Framework. Journal of borderlands studies, v. 18, n. 1, p. 13-25, 2003.

NEWMAN, D. Borders and bordering: towards an interdisciplinary dialogue. European Journal of Social Theory. v. 9, n. 2, p. 171-186, 2006.

NOGUEIRA, R. J. B. Fronteira: espaço de referência identitária? Goiânia: Ateliê Geográfico, v. 1, n. 2, p. 27-41, 2007.

RAFFESTIN, C. Por uma geografia do poder. 1 ed. São Paulo: Ática, 1993. 123p.

SANTOS, M. Manual de Geografia Urbana. São Paulo: Edusp, 2008. 232p.

SILVA, R. M.; OLIVEIRA, T. C. M. O mérito das cidades-gêmeas nos espaços fronteiriços. Observatório Ibero Americano Del Desarrolo Local Y La Economia Social, Málaga, v. 1, n. 5, p. 1-11, 2008.

SOI, I.; NUGENT, P. Peripheral urbanism in Africa: border towns and twin towns in Africa. Journal of Bordelands Studies, v. 32, n. 4, p.535-556, 2017.

SUFRAMA. Áreas de Livre Comércio, Manaus, disponível em: http://www.suframa.gov.br/invest/zona-franca-de-manaus-alc.cfm Acesso em: 21 set. 2018. 
TAGLIACOZZO, E. Jagged landscapes: Conceptualizing borders and boundaries in the history of human societies. Journal of Borderland Studies, v. 31, n. 1, p. 1-21, 2015.

TERENCIANI, C. "Interculturalidade e "Cidades-Gêmeas": ¿novas configurações identitárias? ", en Contribuciones a las Ciencias Sociales, Febrero 2012, disponivel em: www.eumed.net/rev/cccss/18/. Acesso em: 21 set. 2018.

VIRGA, T. Fronteira, urbanização e desenvolvimento na Amazônia sul-americana: compreendendo disparidades nas cidades-gêmeas de Letícia (Colômbia) e Tabatinga (Brasil). Revista Monções, Dourados, v. 6, n. 12, p. 109-133, 2017. 